\title{
Dry Period Length in US Jerseys: Characterization and Effects on Performance
}

\author{
M. T. Kuhn, ${ }^{1}$ J. L. Hutchison, and H. D. Norman \\ Animal Improvement Programs Laboratory, Agricultural Research Service, USDA, Beltsville, MD 20705-2350
}

\begin{abstract}
The objectives of this research were to characterize dry period lengths for US Jerseys, determine the effects of days dry (DD) on subsequent lactation actual milk, fat, and protein yields, fat and protein percentages, somatic cell score (SCS), and days open (DO), and to determine the dry period length that maximizes yield across lactations. Field data, collected through the Dairy Herd Improvement Association, on US Jersey cows first calving between January 1997 and November 2004 were used. Characterization of DD included a frequency distribution of dry period lengths as well as factors affecting US Jersey DD. Of the factors considered in this research, the primary ones affecting dry period length were DO, milk yield, and SCS. Cows with longer DO, lower milk yield, and higher SCS received longer dry periods. The model for analyses included herd-year of calving, year-state-month of calving, parity of calving, previous lactation record, age at calving, and $\mathrm{DD}$ as a categorical variable; records were preadjusted for cow effects. A total of 123,032 records from 73,797 cows in 808 herds were used for estimation of DD effects on subsequent lactation actual milk yield. Jersey milk, fat, and protein yields in the subsequent lactation were maximized with 61 to $65 \mathrm{DD}$. Dry periods of $30 \mathrm{~d}$ or fewer resulted in large reductions in subsequent lactation production. A short dry period was beneficial for fat and protein percentages in the subsequent lactation. Short dry periods also resulted in fewer DO in the subsequent lactation; however, this was entirely due to the lower milk yield associated with shortened dry periods. The biggest difference between Jerseys and Holsteins was a much larger detrimental effect on SCS in Jerseys for dry periods of $30 \mathrm{~d}$ or less. Jersey SCS increased $10 \%$, relative to the overall mean, for dry periods of 20 $\mathrm{d}$ or less and $4.6 \%$ for DD between 21 and $30 \mathrm{~d}$. Dry periods of 45 to $70 \mathrm{~d}$ maximized yields across adjacent lactations. A dry period length, after first lactation,
\end{abstract}

Received October 24, 2006.

Accepted December 15, 2006.

${ }^{1}$ Corresponding author: mkuhn@aipl.arsusda.gov of 45 to $70 \mathrm{~d}$ also maximized actual milk yield across lactations 1,2, and 3. The final recommendation to Jersey producers is to avoid dry periods of $<45 \mathrm{~d}$. Long dry periods ( $>70 \mathrm{~d}$ ) should also be avoided because these are even more costly to total yield than dry periods $<30 \mathrm{~d}$.

Key words: days dry, Jersey, fertility, somatic cell score

\section{INTRODUCTION}

The last 4 to $5 \mathrm{yr}$ have seen a renewed interest in the effects of dry period length on the performance of dairy cattle. Although this topic has received considerable attention in the past (Schaeffer and Henderson, 1972; Coppock et al., 1974; Dias and Allaire, 1982; Funk et al., 1987), dairy cattle populations have changed substantially, both genetically and phenotypically, over the last 20 to $30 \mathrm{yr}$. Selection has brought substantial genetic changes (AIPL, 2006) in all breeds, and management practices have evolved considerably as well. Thus, recent research (Bachman, 2002; Gulay et al., 2003; Kuhn et al., 2005b; Rastani et al., 2005) has explored length of dry period effects for modern-day dairy cattle in modern management systems.

Much of the past research, as well as recent research, on days dry (DD) has focused on effects on subsequent lactation performance, and primarily effects on production. Several studies (Gulay et al., 2003; Annen et al., 2004; Rastani et al., 2005; Kuhn et al., 2006b), however, have examined subsequent lactation effects on other traits such as fertility, SCS, and fat and protein percentages, and one recent study (Kuhn et al., 2006a) examined effects on lifetime performance. Furthermore, research has been conducted on interactions of DD with previous lactation days open (DO), SCS, age at calving, and milk yield (Kuhn et al., 2005b). However, one aspect that has received little attention, if any, in either past or recent research on DD is whether breeds respond differently to variations in dry period length; virtually all research has been conducted using only Holsteins. The objectives of this research were first to characterize dry period lengths for US Jerseys and to determine the effects of DD on subsequent lactation milk, fat, and 
protein yields, fat and protein percentages, SCS, and DO for US Jerseys. Characterization of DD included a frequency distribution of dry period lengths as well as factors affecting US Jersey DD.

Information on the effects of DD in the subsequent lactation is a necessary first step for a complete understanding of the consequences of various dry period lengths. But cows also lose production in the previous lactation because of dry off. A further objective, then, was to determine the dry period length for Jerseys that maximizes yield across adjacent lactations. Even total yield across adjacent lactations, however, is not entirely complete information. If either short or long DD resulted in greater culling late in the lactation following the dry period, then this would be an impact on lifetime performance or value that would not be reflected in the mere total across adjacent lactations. A final objective, then, was to provide some assessment of the potential impact of varying dry period lengths on lifetime performance.

Jerseys were an optimal choice in the United States for examining DD effects in an alternative breed because, although a distant second, Jerseys rank only behind Holsteins in terms of number of cows on test. Thus, adequate sample sizes for research were more likely for Jerseys than for other breeds.

\section{MATERIALS AND METHODS}

\section{General Description of Data}

Data used in this research were DHIA records from the Animal Improvement Programs Laboratory's national database. Only records on Jersey cows first calving in January 1997 or later were eligible for inclusion because dry dates were not stored prior to 1997. Furthermore, actual lactation yields were to be used in this research, in contrast to standardized (mature-equivalent) yields, because research (Kuhn et al., 2005b) has shown that standardized lactation yields conceal variation caused by dry period length. Thus, herds were required to be on continuous test after their first date of inclusion to ensure that the cows included had complete lactations recorded.

Records also had to be initiated no later than November 2004 to be included, which, given that data were extracted from the database in May of 2006, was also done to ensure complete lactations. Thus, calving dates for records included in this research spanned the period of January 1997 to November 2004. Herds were not required to be on test for the entire period; rather, they were only required to be on test continuously, up to May of 2006, after their first date of inclusion. For example, if a herd was not on test until 1999, it was still included provided it remained on test until May of 2006. This alternative resulted in larger sample sizes, compared with requiring herds to be on test continuously from 1997 to 2006.

Additional edits included exclusion of records initiated by abortion and exclusion of cows known to be donor dams, because these factors would result in unexpected or artificially abnormal dry period lengths. Donor dams can be identified from 2 sources of information in the Animal Improvement Programs Laboratory database: 1) pedigrees supplied by the breed association that identify calves as "ET" (embryo transfer) and thus their dams as donor dams; and 2) the reproductive record known as format 5, which allows reporting of donor dams. Another edit was to require actual calving dates to be within $10 \mathrm{~d}$ of the expected calving date, given the last reported breeding date, which ensured that the owner knew, at least at one point in time, when the cow was going to calve. Finally, any herd that had fewer than 5 cows in any year was deleted, which was done to ensure adequate sample size for adjustment of herd effects.

Actual lactational yields for milk, fat, and protein were calculated using the test-interval method (Sargent et al., 1968) and the lactation shape adjustment factors of Shook et al. (1980). The only standardization done was to a twice-daily milking basis. Records less than $305 \mathrm{~d}$ were not extended to $305 \mathrm{~d}$, and all production beyond $305 \mathrm{~d}$ was included.

\section{Factors Affecting Dry Period Length}

To determine the effects of DD on performance following the dry period, the trait of interest (e.g., milk yield) would be the dependent variable and DD an independent variable in the model. However, to determine how various factors affect dry period length, the opposite is done; DD becomes the dependent variable and factors from the lactation preceding the dry period (previous lactation) are the independent variables of interest.

The linear fixed effects model used for assessment of factors affecting dry period length in US Jerseys was:

$$
\begin{gathered}
\mathrm{DD}=\text { Herd }+ \text { Yr }+ \text { Mo }+ \text { Parity }+ \text { Age }+ \text { DO } \\
+ \text { Milk + Last_SCS }+ \text { e }
\end{gathered}
$$

where Herd, Yr, Mo, and parity were herd, year, month, and parity of calving in the lactation preceding the dry period; Age and DO were age at calving and DO in the previous lactation; Milk was the actual lactational milk yield in the previous lactation; and Last_SCS was the SCS on the last test-day in the previous lactation. Age, DO, milk, and Last_SCS were all fit as categorical variables. Categories for age were defined as follows: 1) 2 yr of age or younger, 2) 2 to $2.5 \mathrm{yr}, 3) 2.5$ to $3 \mathrm{yr}, 4) 3$ 
Table 1. Factors affecting days dry analysis: category means for actual lactational milk yield $(\mathrm{kg})$, last test-day SCS, and days open

\begin{tabular}{lccc}
\hline Category & Milk & SCS & Days open \\
\hline 1 & 5,421 & 1.6 & 62 \\
2 & 7,240 & 3.3 & 97 \\
3 & 9,735 & 5.3 & 187 \\
\hline
\end{tabular}

to $3.5 \mathrm{yr}, 5) 3.5$ to $4 \mathrm{yr}$, and 6 ) older then $4 \mathrm{yr}$. Categories for milk, Last_SCS, and DO were defined as follows: 1 ) lower third of data sorted by trait, 2) middle third of data, and 3) top third of data. Arithmetic means of milk, SCS, and DO subclasses are given in Table 1.

Data for analysis of factors affecting DD included calvings only up to the year 2004; that is, previous calving years (the year preceding the dry period) went up to only 2003. Only a small fraction of the cows calving in 2005 would have had sufficient time to calve again and thus be included in this analysis. After restricting to cows calving no later than the year 2004, a total of 115,865 records from 790 herds in 44 states were included for this analysis. Least squares means, SAS type III mean squares (SAS Institute, 2004), and significance levels were computed for each effect in the model. Mean squares were used to assess the relative importance of each factor.

\section{Analysis of DD Effects on Subsequent Lactation Performance}

General Considerations and Further Description of Data. Studies that had the capability to estimate DD effects over a basically continuous range of dry period lengths have generally found that subsequent lactation performance does not change either linearly or quadratically over a range of DD from 0 to $100 \mathrm{~d}$ or more. On the contrary, subsequent lactation milk yield, for example, has been reported to increase at a decreasing rate up to about $60 \mathrm{DD}$, at which point production essentially levels off (Funk et al., 1987; Makuza and McDaniel, 1996; Kuhn et al., 2005b). This implies that DD effects cannot be appropriately modeled with simple linear or quadratic covariates. Furthermore, use of any covariates necessarily dictates the nature of the relationship between the variables of interest, but the objective in this research was to discover the nature of the relationship between performance and DD; use of DD as a categorical variable allows for direct and straightforward examinations of those relationships. Thus, DD categories were formed for analysis and are presented in Table 2. Categories used for analysis (Table 2) represented a compromise between the desire for categories with a small range for $\mathrm{DD}$, which provide the maximum amount of information with regard to how performance changes as DD changes, and the need for reasonable sample sizes for estimation.

Dry period lengths beyond $130 \mathrm{~d}$ were infrequent. Furthermore, such records may be indicative of some unknown peculiarity about the cow or that particular lactation. Unusually long dry periods might, for example, be reflecting undetected flush cows, injuries, or perhaps even preferentially treated cows because culling might be expected rather than toleration of exceptionally long dry periods. Records with dry periods longer than $130 \mathrm{~d}$, then, would have contributed very little to analyses, may be suspect, and thus were excluded from analysis.

Several studies using Holsteins (Funk et al., 1987; Kuhn et al., 2005b) have investigated whether the effect of dry period length in the subsequent lactation depends on parity and have generally found either no or only small interactions with parity. Furthermore, even when DD effects were found to differ slightly across parities, the dry period length to maximize subsequent lactation performance was generally the same regardless of parity. Kuhn et al. (2005b), for example, found that dry periods of less than $20 \mathrm{~d}$ decreased subsequent lactation milk yield for Holsteins more in the second lactation than in later lactations, but $60 \mathrm{DD}$ maximized yield in the following lactation regardless of parity. Preliminary results (presented graphically in the Results and Discussion section) indicated similar results for milk yield in Jerseys. Furthermore, sample sizes by parity, especially for third and fourth lactations, were rather small. Thus, the final analyses for effects of DD on subsequent lactation performance used all lactations combined in a single analysis, in contrast to separate analyses for each parity. The final number of records for each DD subclass and for each trait is given in Table 2 , along with the total number of herds for each trait. For example, a total 123,032 records from 73,797 cows in 808 herds and 44 states were used for estimation of DD effects on subsequent lactation actual milk yield.

The major factor affecting sample size was more availability of data, rather than edits (eliminating available records) per se. The requirement for herds to be on continuous test, for example, eliminated about one-third of the herds with Jersey cows. Furthermore, not all processing centers began sending complete lactation information (needed for calculation of actual records) at the same time, which meant that not all records back to 1997 could be kept for all processing centers; that is, the date of first possible inclusion had to be moved forward for some herds, depending on the processing center. This editing by the processing center eliminated approximately 300,000 records. Given a US culling rate after first lactation of about 35 to $40 \%$, the requirement for cows to have at least 2 lactations (and 
Table 2. Days dry categories, corresponding dry period lengths, and sample sizes for milk, fat, protein, SCS, and days open, along with total number of records, cows, and herds for each trait

\begin{tabular}{|c|c|c|c|c|c|c|}
\hline $\begin{array}{l}\text { Days dry } \\
\text { category }\end{array}$ & Days dry & Milk & Fat & Protein & SCS & Days open \\
\hline 1 & $0-20$ & 1,289 & 1,209 & 1,207 & 1,230 & 1,174 \\
\hline 2 & $21-30$ & 1,200 & 1,137 & 1,136 & 1,161 & 1,132 \\
\hline 3 & $31-40$ & 4,655 & 4,378 & 4,375 & 4,453 & 4,456 \\
\hline 4 & $41-45$ & 6,921 & 6,468 & 6,463 & 6,643 & 6,599 \\
\hline 5 & $46-50$ & 13,630 & 12,759 & 12,741 & 13,221 & 13,119 \\
\hline 6 & $51-55$ & 22,340 & 20,852 & 20,805 & 21,819 & 21,614 \\
\hline 7 & $56-60$ & 27,493 & 26,003 & 25,941 & 26,916 & 26,661 \\
\hline 8 & $61-65$ & 21,315 & 20,233 & 20,167 & 20,860 & 20,714 \\
\hline 9 & $66-70$ & 10,255 & 9,727 & 9,692 & 10,040 & 9,954 \\
\hline 10 & $71-80$ & 6,198 & 5,887 & 5,871 & 6,067 & 5,960 \\
\hline 11 & $81-90$ & 2,713 & 2,558 & 2,551 & 2,656 & 2,590 \\
\hline 12 & $91-110$ & 3,160 & 2,933 & 2,927 & 3,096 & 3,006 \\
\hline 13 & $111-130$ & 1,863 & 1,743 & 1,743 & 1,811 & 1,757 \\
\hline Total records & & 123,032 & 115,887 & 115,619 & 119,973 & 118,736 \\
\hline Total cows & & 73,797 & 69,688 & 69,520 & 72,063 & 71,747 \\
\hline Total herds & & 808 & 804 & 801 & 800 & 806 \\
\hline
\end{tabular}

thus at least 1 dry period) also had a substantial impact on the number of records available for final analysis. Methodology (described below) also imposed some data requirements, most importantly that cows had an available first lactation. Thus, in a herd's first year of inclusion, only first-lactation cows would be eligible. If the milking herd size was 100 cows, for example, with 35 first-lactation cows, then only 35 cows were eligible for inclusion for that year and of those 35, only those making a second lactation could be included.

Estimation of DD Effects. Dry period length has been found to be correlated with cow effects (Kuhn and Hutchison, 2005); cows with a higher producing ability tend to get shorter dry periods. Thus, methods for analysis must adjust for cow effects to avoid underestimation of short dry period effects (confounding with positive cow effects would tend to bias estimates of short DD effects upward). Kuhn and Hutchison (2005) showed that prior adjustment of records for cow effects, estimated from an animal model, would provide estimates of DD effects that are unbiased by cow effects. Thus, cow effects (sum of animal and permanent environmental effects) were estimated for each trait using multiple trait animal models. Multiple, rather than single, trait models were used for estimation of cow effects to improve the accuracy of estimates. Two- and 3-trait models were used for estimation of cow effects; actual milk, fat, and protein yields were analyzed simultaneously; fat and protein percentages were combined in a 2-trait model; and SCS and DO were each analyzed simultaneously with milk yield. In addition to the random animal and permanent environmental effects, the models for estimation of cow effects included the fixed effects of herd-year of calving, year-state-month of calving, age at calving, and DD fit as a categorical variable.
For estimation of cow effects, cows were required to have a first-lactation record, but not a second or later lactation. First lactations needed to be included in these analyses to avoid bias in the estimates of cow effects. Because there are no DD associated with a first lactation, first-parity records were assigned their own unique DD category, which was part of the method of Kuhn and Hutchison (2005).

After adjusting for cow effects, the same linear, fixed effects model was used for analysis of all traits:

$$
\begin{aligned}
\mathrm{y}^{*}= & \mathrm{HY}+\text { Yr-St-Mo }+ \text { Parity }+\beta_{1} \times \text { Age }+\beta_{2} \\
& \times \mathrm{Age}^{2}+\beta_{3} \times \text { PrevRecord }+ \text { DD }+\mathrm{e}
\end{aligned}
$$

where $\mathrm{y}^{*}$ was an actual lactational milk, fat, or protein yield, fat or protein percentage, SCS, or DO record adjusted for cow effects; HY was herd-year of calving; YrSt-Mo and parity were year-state-month and parity of calving; Age was age at calving fit as a linear and quadratic covariate; $\beta_{3} \times$ PrevRecord was a regression on the previous lactation record, the use of which has been shown to improve the accuracy of estimates (Kuhn and Hutchison, 2005), even with records adjusted for cow effects; DD was a categorical DD variable with categories as defined in Table 2; and e was random error. Month effects were allowed to vary by year and state because climate can vary considerably from year to year in the United States and from region to region within a year. Month was fit separately from herd-year to avoid small group sizes. Overall arithmetic means for each trait are given in Table 3.

\section{DD to Maximize Actual Milk Yield Across Lactations}

Maximizing Yield Across Adjacent Lactations. The dependent variables for determination of DD ef- 
Table 3. Arithmetic means for milk, fat, and protein yields (kg), fat and protein percentages, SCS, and days open for records used in subsequent lactation analyses

\begin{tabular}{lcc}
\hline Trait & Mean & SD \\
\hline Milk & 7,700 & 2,487 \\
Fat & 356 & 120 \\
Protein & 275 & 90 \\
Fat \% & 4.62 & 0.57 \\
Protein \% & 3.57 & 0.26 \\
SCS & 3.06 & 1.47 \\
Days open & 128 & 80 \\
\hline
\end{tabular}

fects on actual milk yield across lactations was the sum of lactational yields across adjacent lactations. Two lactational sums were examined: total yield across lactations 1 and 2 (Sum12) and total yield across lactations 2 and 3 (Sum23). Sample sizes for totals across other later lactations were too small for meaningful analysis. In contrast to investigations on effects in the subsequent lactation, Sum 12 and Sum 23 were analyzed separately because initial investigation indicated considerably different results for short dry periods for the 2 different sums. Similar to the studies on subsequent lactation effects, both sums were preadjusted for cow effects prior to analysis. In addition to the DD category variable, the model for analysis of both Sum12 and Sum23 included the fixed effects of herd-year and yearstate-month of calving and the linear and quadratic effects of age at calving. Herd-year, year-state-month, and age at calving were from the first of the 2 lactations in the sum (e.g., lactation 1 for Sum12). Categories for DD were the same as those used for subsequent lactation analyses (Table 2).

Dry Period Length to Maximize Yield Across Multiple Lactations. This issue has been addressed in previous research with Holsteins using lifetime actual milk yield (Kuhn et al., 2006a). Analyses of lifetime yield, however, require that cows have sufficient time to complete their lifetimes, which means that data from only the earliest several years can be used, and this restriction resulted in sample sizes too small to study lifetime Jersey yield. The question at hand is whether short (or long) dry periods result in additional culling or other carryover effects that would not be detected by an analysis of sums across adjacent lactations. For example, shortened dry periods could result in essentially no milk yield loss across lactations 1 and 2, but if the shorter DD caused additional culling toward the end of lactation 2, this would not be reflected in Sum12, but it would be of economic importance. Given the potential economic importance of this question and the present interest in using shortened dry periods, some investigation on this topic would be of value, in spite of insufficient data for lifetime yield.
Table 4. Distribution of Jersey dry period lengths

\begin{tabular}{lrcc}
\hline Days dry & Frequency & Percentage & $\begin{array}{c}\text { Cumulative } \\
\text { percentage }\end{array}$ \\
\hline $0-10$ & 16,637 & 4.12 & 4.12 \\
$11-20$ & 830 & 0.21 & 4.33 \\
$21-30$ & 2,327 & 0.58 & 4.91 \\
$31-40$ & 8,580 & 2.13 & 7.03 \\
$41-45$ & 12,223 & 3.03 & 10.07 \\
$46-50$ & 23,502 & 5.83 & 15.89 \\
$51-55$ & 37,840 & 9.38 & 25.27 \\
$56-60$ & 213,386 & 52.90 & 78.18 \\
$61-65$ & 36,374 & 9.02 & 87.20 \\
$66-70$ & 18,147 & 4.50 & 91.69 \\
$71-80$ & 11,729 & 2.91 & 94.60 \\
$81-90$ & 5,257 & 1.30 & 95.91 \\
$91-110$ & 6,243 & 1.55 & 97.45 \\
$111-130$ & 3,586 & 0.89 & 98.34 \\
$>130$ & 6,685 & 1.66 & 100.00 \\
\hline
\end{tabular}

An alternative approach, to partly address whether DD has effects on lifetime performance, would be to use total yield across lactations 1, 2, and 3 (Sum123) in place of lifetime yield, and to examine the effects of the first dry period length (DD1) on Sum123. The Sum123 would detect detrimental or beneficial effects that DD1 had at the end of or after lactation 2. Thus, Sum123 was preadjusted for cow effects (breeding value, because each cow had only 1 record) and analyzed with a model that included the fixed effects of herd-year and year-state-month of first calving, age at first calving, and DD1. Categories for DD1 were the same as those for the subsequent lactation analyses (Table 2). Data were restricted to cows that first calved no later than December 2002 to allow the cows adequate time to complete 3 lactations. The arithmetic means for Sum12, Sum23, and Sum123 were 14,633, 15,691, and 19,065 $\mathrm{kg}$, respectively. An analysis to examine the effects of the second dry period on total yield across lactations 2 , 3 , and 4 (analogous to Sum123) was considered, but sample sizes were too small to make effective inferences.

\section{RESULTS AND DISCUSSION}

\section{Distribution of Dry Period Lengths and Factors Affecting $D D$}

The distribution of dry period lengths for US Jerseys calving between January 1997 and November 2004 is given in Table 4. Although, the distribution for Jerseys was similar to that for Holsteins reported by Kuhn et al. (2005a), there were some differences. About $77 \%$ of all Jersey dry periods were between 46 and $65 \mathrm{~d}$, which is higher than the $65 \%$ for Holsteins. About $5 \%$ of Jersey dry periods were $30 \mathrm{~d}$ or less, which is considerably higher than the $1.64 \%$ reported for Holsteins. Roughly 
Table 5. Mean squares for factors affecting days dry

\begin{tabular}{lrr}
\hline Effect $^{1}$ & df & \multicolumn{1}{c}{ MS } \\
\hline Days open & 2 & 541,605 \\
Lactational milk yield & 2 & 482,400 \\
Last test-day SCS & 2 & 52,420 \\
Herd & 789 & 5,144 \\
Parity & 5 & 5,044 \\
Calving year & 6 & 3,692 \\
Calving month & 11 & 2,095 \\
Calving age & 5 & 1,019 \\
Error & 115,042 & 190 \\
\hline
\end{tabular}

${ }^{1}$ All effects significant with $P<0.0001$.

$5 \%$ of Jerseys had dry periods of $80 \mathrm{~d}$ or more, whereas nearly $8 \%$ of Holstein dry periods were $80 \mathrm{~d}$ or more.

Mean squares, sorted by magnitude, are given in Table 5 for each factor included for investigation of variation in DD. The major factors affecting DD for Jerseys were the same as for Holsteins. Days open and milk yield had, by far, the largest impact on DD, followed by last test-day SCS. Although all factors were statistically significant, the remaining factors, including herd, had more minor effects on DD.

Least squares means for each factor are presented in Table 6. Longer DO, the major factor affecting DD, results in longer dry periods. Cows with long open periods likely receive extended lactations until their milk yield drops to a point where it is no longer worthwhile to keep them in milk, at which point they are dried off; that is, cows with long DO essentially receive an "involuntary" long dry period. Given that Jerseys average about 17 fewer DO than Holsteins (AIPL, 2006), DO might be expected to have less impact on Jersey DD than on Holstein DD, but results for Jerseys were nearly identical to those for Holsteins as reported by Kuhn et al. (2006b). The reason for this may be that the Holstein sustains a higher level of milk yield in late lactation and is subsequently kept in milk for a longer period of time, which then partially offsets the longer DO.

Similar to Holsteins, Jersey cows with lower milk yields get about 10 more DD than cows with the highest milk yields. Here again, daily production for lower producing cows likely drops to a point at which it is simply not worthwhile to keep them in milk, so they are dried off and receive a longer dry period.

Given that the Jersey average for SCS is about 0.3 higher than for Holsteins (AIPL, 2006), SCS might be expected to play a larger role in dry period length for Jerseys than for Holsteins; however, results for Jerseys were nearly identical to those reported by Kuhn et al. (2006b) for Holsteins. The main difference among the SCS groups was about 2.4 more DD for cows with the highest SCS, whereas there was very little difference
Table 6. Least squares means and standard errors for factors affecting days dry

\begin{tabular}{|c|c|c|c|}
\hline Category & Effect & LSM & $\mathrm{SE}$ \\
\hline \multirow[t]{3}{*}{ Day open } & Shortest & 56.1 & 0.24 \\
\hline & Medium & 59.0 & 0.24 \\
\hline & Longest & 65.0 & 0.24 \\
\hline \multirow{3}{*}{ Lactational milk } & Lowest third & 65.1 & 0.24 \\
\hline & Middle third & 59.4 & 0.24 \\
\hline & Highest third & 55.5 & 0.24 \\
\hline \multirow[t]{3}{*}{ Last test-day SCS } & Lowest third & 59.2 & 0.24 \\
\hline & Middle third & 59.4 & 0.24 \\
\hline & Highest third & 61.5 & 0.23 \\
\hline \multirow[t]{6}{*}{ Parity } & 1 & 56.7 & 0.24 \\
\hline & 2 & 59.9 & 0.19 \\
\hline & 3 & 60.3 & 0.28 \\
\hline & 4 & 60.8 & 0.35 \\
\hline & 5 & 61.4 & 0.42 \\
\hline & 6 & 61.0 & 0.70 \\
\hline \multirow[t]{7}{*}{ Calving year } & 1997 & 61.6 & 0.28 \\
\hline & 1998 & 60.4 & 0.25 \\
\hline & 1999 & 60.5 & 0.24 \\
\hline & 2000 & 60.4 & 0.24 \\
\hline & 2001 & 60.3 & 0.22 \\
\hline & 2002 & 59.7 & 0.22 \\
\hline & 2003 & 57.2 & 0.61 \\
\hline \multirow[t]{12}{*}{ Calving month } & January & 61.0 & 0.26 \\
\hline & February & 60.5 & 0.27 \\
\hline & March & 60.4 & 0.26 \\
\hline & April & 60.0 & 0.27 \\
\hline & May & 59.8 & 0.27 \\
\hline & June & 59.7 & 0.27 \\
\hline & July & 59.6 & 0.27 \\
\hline & August & 59.4 & 0.27 \\
\hline & September & 59.5 & 0.26 \\
\hline & October & 59.7 & 0.26 \\
\hline & November & 60.1 & 0.27 \\
\hline & December & 60.4 & 0.27 \\
\hline \multirow{6}{*}{ Calving age } & $<24 \mathrm{mo}$ & 59.0 & 0.39 \\
\hline & 24 to $<30 \mathrm{mo}$ & 59.4 & 0.38 \\
\hline & 30 to $<36 \mathrm{mo}$ & 60.2 & 0.29 \\
\hline & 36 to $<42 \mathrm{mo}$ & 60.3 & 0.29 \\
\hline & 42 to $<48 \mathrm{mo}$ & 60.7 & 0.24 \\
\hline & $>48 \mathrm{mo}$ & 60.6 & 0.21 \\
\hline
\end{tabular}

in DD between the first 2 groups for either breed. Thus, the highest SCS group probably includes mastitic cows and, as such, represents a sort of threshold at which SCS begins to affect dry period length; cows with mastitis are dried off, but otherwise SCS has little or no effect on dry period length.

The most notable effect of parity on dry period length was for first-parity cows to average about 3 to 5 fewer DD than later parity cows. This is likely due to the greater persistency of first-lactation cows (Stanton et al., 1992). Thus, although cows produce more total milk over the entire lactation in second and later lactations, first-lactation cows actually have higher yields at the end of lactation, which in turn leads to slightly longer lactations, on average, and fewer DD.

The primary difference among years was that the last year included (2003) had a 2- to 3-d lower mean than previous years. Although there may be some trend 


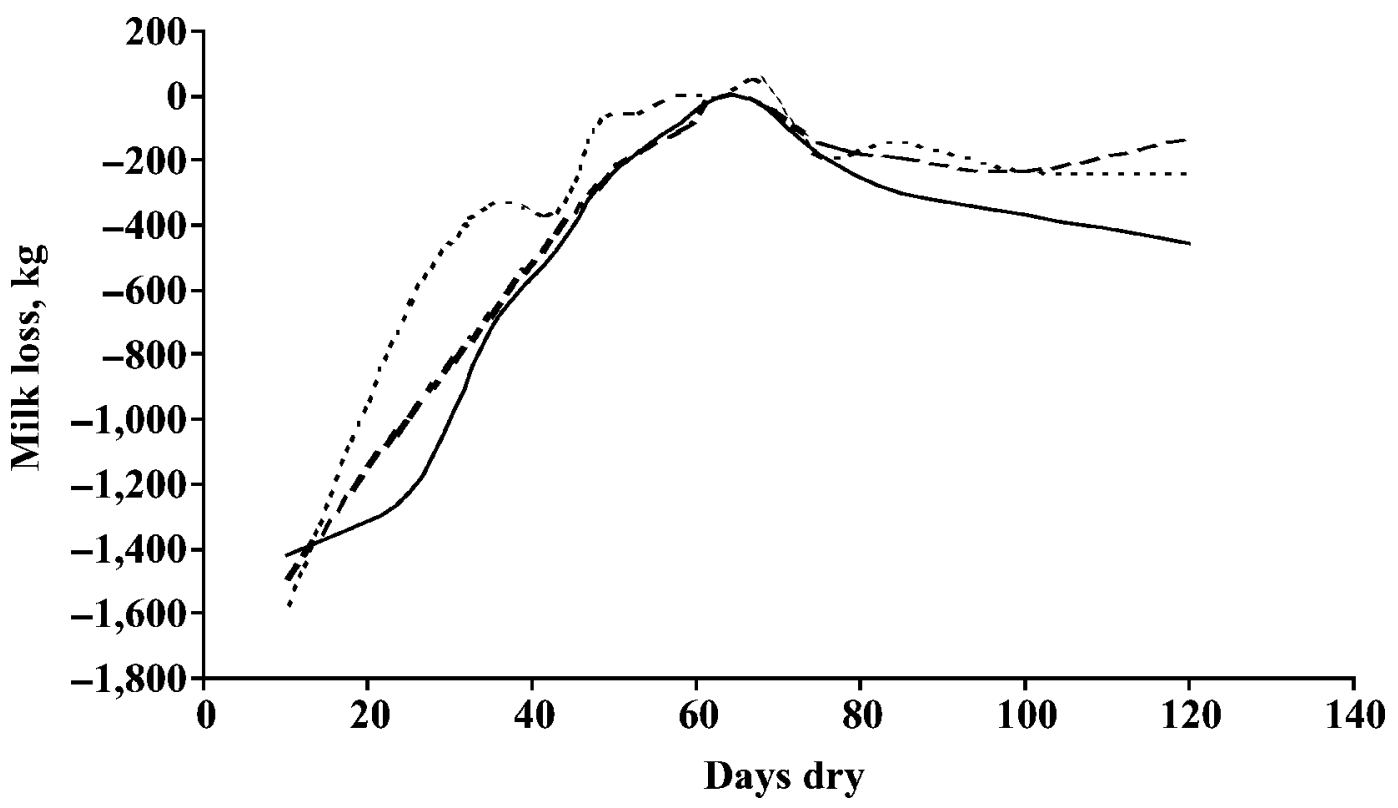

Figure 1. Effect of dry period length on actual milk yield in the subsequent lactation, by parity: parity 2 (solid line), parity 3 (dashed line), and parity 4 (dotted line).

toward shorter dry periods in Jerseys, this year effect probably reflects a slight bias in this analysis for this particular factor; for cows calving in 2004 (previous year $=2003$ ), those with the shortest dry periods would have more of a chance to calve again, and thus be included in the data, than cows with the longest dry periods.

\section{Effects on Subsequent Lactation Performance}

Milk, Fat, and Protein Yields. The preliminary results for actual milk yield by parity are illustrated in Figure 1. Although the graphs are not identical for all 3 parities, Figure 1 certainly illustrates no dramatic difference in DD effects across parities for subsequent lactation production. Furthermore, standard errors were rather large for parity 3 , and especially parity 4 . The $P$-value for the parity $\times \mathrm{DD}$ interaction was 0.0501 , which, for an $F$-test with 24 numerator and 115,802 denominator degrees of freedom, is not particularly low (not "highly significant"). Thus, little, if any, information was lost by analysis of all parities combined.

Results for actual lactational milk, fat, and protein yields are given in Table 7. Estimates in Table 7 are expressed relative to category 8 (61 to $65 \mathrm{DD})$. As an example of interpretation, the $-1,457 \mathrm{~kg}$ of milk in the first DD category means that cows with 20 or fewer DD produce $1,457 \mathrm{~kg}$ less milk, on average, than cows with 61 to $65 \mathrm{DD}$.

Actual milk, fat, and protein production was maximized in the subsequent lactation with 61 to $65 \mathrm{DD}$.
Although there was no particular threshold dry period length less than $60 \mathrm{~d}$ at which production losses became nil, it is worthwhile to emphasize that losses were large for dry periods of $40 \mathrm{~d}$ or less, and especially large for dry periods of $30 \mathrm{~d}$ or less. Jersey cows produced 1,457 $\mathrm{kg}$ less milk, $63 \mathrm{~kg}$ less fat, and $48 \mathrm{~kg}$ less protein in lactations following dry periods of $20 \mathrm{~d}$ or less. Even with 21 to $30 \mathrm{DD}$, losses were still substantial; cows with only 21 to $30 \mathrm{DD}$ produced 1,080 kg less milk, for example, than cows with 61 to $65 \mathrm{DD}$. Lost production in the subsequent lactation was reduced considerably, however, with a minimum $46 \mathrm{DD}$, and losses with a minimum of $51 \mathrm{DD}$ were small.

Not only did shortened dry periods result in lost production in the subsequent lactation, but also dry periods longer than $60 \mathrm{~d}$ were associated with production lower than that for $60 \mathrm{DD}$, although the reduction in subsequent lactation for DD >60 was far less than for short DD. A similar result has been reported for Holsteins (Kuhn et al., 2005b, 2006b). The reason for lower production with dry periods $>60 \mathrm{~d}$ is unknown. Kuhn and Hutchison (2005) showed, using simulation, that the methodology used in this research provides unbiased estimates for dry periods beyond the point at which milk yield is maximized. Furthermore, Funk et al. (1987) and Schaeffer and Henderson (1972) also found lower milk yields for DD >60, using alternative methodologies; Funk et al. (1987) included only a cow effect with no relationships and Schaeffer Henderson (1972) used a sire model with no relationships. Thus, the result of 
Table 7. Effects of dry period length on subsequent lactation actual milk, fat, and protein yields ${ }^{1}$

\begin{tabular}{lcccc}
\hline $\begin{array}{l}\text { Days dry } \\
\text { category }\end{array}$ & Days dry & Milk, kg & Fat, kg & Protein, kg \\
\hline 1 & $0-20$ & $-1,457 \pm 52.6^{* * * *}$ & $-63 \pm 2.7^{* * *}$ & $-48 \pm 2.0^{* * * *}$ \\
2 & $21-30$ & $-1,080 \pm 52.9^{* * *}$ & $-46 \pm 2.7^{* * *}$ & $-34 \pm 2.0^{* * *}$ \\
3 & $31-40$ & $-664 \pm 29.6^{* * *}$ & $-28 \pm 1.5^{* * *}$ & $-20 \pm 1.1^{* * *}$ \\
4 & $41-45$ & $-451 \pm 24.9^{* * *}$ & $-18 \pm 1.3^{* * *}$ & $-13 \pm 0.9^{* * * *}$ \\
5 & $46-50$ & $-255 \pm 19.6^{* * *}$ & $-9 \pm 1.0^{* * *}$ & $-7 \pm 0.7^{* * *}$ \\
6 & $51-55$ & $-162 \pm 16.6^{* * *}$ & $-6 \pm 0.8^{* * *}$ & $-4 \pm 0.6^{* * * *}$ \\
7 & $56-60$ & $-83 \pm 15.3^{* * *}$ & $-2 \pm 0.8^{* *}$ & $-2 \pm 0.6^{* * *}$ \\
8 & $61-65$ & 0 & 0 & 0 \\
9 & $66-70$ & $-13 \pm 20.1$ & $0 \pm 1.0$ & $-1 \pm 0.8$ \\
10 & $71-80$ & $-147 \pm 24.7^{* * *}$ & $-7 \pm 1.2^{* * *}$ & $-7 \pm 0.9^{* * *}$ \\
11 & $81-90$ & $-234 \pm 34.7^{* * *}$ & $-12 \pm 1.7^{* * *}$ & $-11 \pm 1.3^{* * *}$ \\
12 & $91-110$ & $-300 \pm 32.7^{* * *}$ & $-14 \pm 1.6^{* * *}$ & $-14 \pm 1.2^{* * *}$ \\
13 & $111-130$ & $-321 \pm 41.3^{* * *}$ & $-16 \pm 2.1^{* * *}$ & $-15 \pm 1.6^{* * *}$ \\
\hline
\end{tabular}

${ }^{1}$ Difference $(\mathrm{kg})$ of: days dry category $i$ minus days dry category $8 \pm$ SE of difference, where $i=1$ to 13 ; $P$-values correspond to a 2 -tailed $t$-test for the null hypothesis of no difference between category $i$ and category 8.

$* * P \leq 0.01 ; * * * P \leq 0.001$.

lower milk yield with dry periods longer than $60 \mathrm{~d}$ does not appear to be caused by inadequate adjustment for cow effects or an artifact of methodology; it may be that cows become overconditioned during dry periods of more than $60 \mathrm{~d}$.

Compared with results for Holsteins reported by Kuhn et al. (2005b), the absolute amount of loss in production for dry periods less than $60 \mathrm{~d}$ was less for Jerseys than for Holsteins. Holsteins, for example, averaged 2,214 kg less milk yield in lactations following dry periods of $20 \mathrm{~d}$ or less, whereas Jerseys averaged only $1,457 \mathrm{~kg}$ less actual milk. On a percentage basis, however (differences expressed relative to the overall arithmetic mean for each breed), losses for Jerseys were essentially the same as those for Holsteins. Production for Jerseys with 20 or fewer DD, for example, was $18.9 \%$ less than for $60 \mathrm{DD}$, whereas the corresponding loss in production for Holsteins was $19.4 \%$. Thus, with regard to effects of DD on subsequent lactation production, there appears to be little difference between Holsteins and Jerseys. Differences among DD subclasses for $4 \%$ FCM (NRC, 1989) were similar for the 2 breeds, except that losses for DD $<30$ were about $400 \mathrm{~kg}$ larger for Holsteins than for Jerseys.

Most previous research, both past and recent, supports the general finding of lower production following dry periods of less than $60 \mathrm{~d}$. Sørensen and Enevoldsen (1991) reported $3.1 \mathrm{~kg} / \mathrm{d}$ lower milk yield for cows with 4- vs. 10-wk dry periods and Rémond et al. (1992) found a $4.1 \mathrm{~kg} / \mathrm{d}$ loss for cows with $0 \mathrm{DD}$, compared with cows with 60 DD. Rastani et al. (2005) found a $4.5 \mathrm{~kg} / \mathrm{d}$ loss for cows with 28 vs. $56 \mathrm{DD}$ and an $8.6 \mathrm{~kg} / \mathrm{d}$ loss for cows with no dry period. Gulay et al. (2005) also reported an $18.9 \%$ reduction in milk yield for dry periods of $30 \mathrm{~d}$ compared with dry periods of $70 \mathrm{~d}$. Earlier research using large data sets of field records (Schaeffer and Henderson, 1972; Coppock et al., 1974; Dias and Allaire, 1982; Funk et al., 1987; Makuza and McDaniel, 1996) all reported lower yields for dry periods less than 60 d. Capuco et al. (1997) showed that a dry period was necessary to replace mammary epithelial cells, thus providing one biological basis for the lower milk yield that has been observed with shortened dry periods. Results of Annen et al. (2004) provided some indication that it may be possible to reduce or eliminate these losses with the use of bST, but given their small sample sizes, further research would be needed to confirm this. The evidence for lower yields in lactations following dry periods $<60 \mathrm{~d}$ is substantial. Only 2 studies (Bachman, 2002; Gulay et al., 2003) have reported no loss with dry periods $<60 \mathrm{~d}$. Sample sizes in both of those studies were small, however, and it has been shown (Kuhn and Hutchison, 2005) that even estimates in the wrong direction are not unlikely with such small sample sizes.

Fat and Protein Percentages. Results for fat and protein percentages are given in Table 8 . In contrast to fat and protein yields, short dry periods actually favored fat and protein percentages. Cows with less than $20 \mathrm{DD}$, for example, averaged 0.08 (fat) and 0.09 (protein) higher percentages than cows with 61 to 65 DD. In fact, lactational percentages for both fat and protein decreased with increasing DD. The higher percentages were not due to the lower milk yields associated with the shorter dry periods because when milk yield was included as a covariate for percentages, estimates were nearly identical to those without milk yield in the model.

Rémond et al. (1992), Rastani et al. (2005), and Madsen et al. (2004) also found higher protein percentages for cows with no dry period. In general, Annen et al. 
Table 8. Effects of dry period length on subsequent lactation actual fat percentage, protein percentage, and $\operatorname{SCS}^{1}$

\begin{tabular}{lcccc}
\hline $\begin{array}{l}\text { Days dry } \\
\text { category }\end{array}$ & Days dry & Fat, $\%$ & Protein, $\%$ & SCS \\
\hline 1 & $0-20$ & $0.08 \pm 0.012^{* * * *}$ & $0.09 \pm 0.011^{* * *}$ & $0.31 \pm 0.033^{* * *}$ \\
2 & $21-30$ & $0.03 \pm 0.012^{*}$ & $0.06 \pm 0.011^{* * *}$ & $0.14 \pm 0.033^{* * *}$ \\
3 & $31-40$ & $0.03 \pm 0.007^{* * *}$ & $0.06 \pm 0.006^{* * *}$ & $0.08 \pm 0.018^{* * *}$ \\
4 & $41-45$ & $0.03 \pm 0.006^{* * *}$ & $0.04 \pm 0.005^{* * *}$ & $0.02 \pm 0.015$ \\
5 & $46-50$ & $0.03 \pm 0.005^{* * *}$ & $0.03 \pm 0.004^{* * *}$ & $0.01 \pm 0.012$ \\
6 & $51-55$ & $0.02 \pm 0.004^{* * *}$ & $0.02 \pm 0.003^{* * *}$ & $0.00 \pm 0.010$ \\
7 & $56-60$ & $0.01 \pm 0.004^{* *}$ & $0.01 \pm 0.003^{* * *}$ & $0.00 \pm 0.009$ \\
8 & $61-65$ & 0 & 0 & 0 \\
9 & $66-70$ & $0.00 \pm 0.005$ & $-0.01 \pm 0.004^{*}$ & $0.02 \pm 0.012$ \\
10 & $71-80$ & $-0.01 \pm 0.006$ & $-0.02 \pm 0.005^{* * *}$ & $0.05 \pm 0.015^{* * *}$ \\
11 & $81-90$ & $-0.02 \pm 0.008^{*}$ & $-0.03 \pm 0.007^{* * *}$ & $0.09 \pm 0.021^{* * *}$ \\
12 & $91-110$ & $-0.02 \pm 0.008^{* *}$ & $-0.04 \pm 0.007^{* * *}$ & $0.09 \pm 0.020^{* * *}$ \\
13 & $111-130$ & $-0.02 \pm 0.010^{*}$ & $-0.05 \pm 0.008^{* * *}$ & $0.06 \pm 0.025^{*}$ \\
\hline
\end{tabular}

${ }^{1}$ Difference $(\mathrm{kg})$ of: days dry category $i$ minus days dry category $8 \pm \mathrm{SE}$ of difference, where $i=1$ to 13 ; $P$-values correspond to a 2 -tailed $t$-test for the null hypothesis of no difference between category $i$ and category 8.

$* P \leq 0.05 ; * * P \leq 0.01 ; * * * P \leq 0.001$.

(2004) also found higher fat and protein percentages with fewer DD, at least for second-lactation cows. In contrast to the results of this study, Gulay et al. (2003) found a 0.06 higher fat percentage for $60 \mathrm{DD}$ compared with $30 \mathrm{DD}$, but considered only the first $10 \mathrm{wk}$ of lactation. However, they also reported a 0.11 lower protein percentage for $60 \mathrm{DD}$, which is consistent, at least in direction, with the results of this study. Variation among results is expected when sample sizes are small (Kuhn and Hutchison, 2005), as it was in the designed trials just discussed. Nonetheless, the general result of lower fat and protein yields but higher fat and protein percentages has been fairly consistent across studies.

Kuhn et al. (2006b) reported results for Holsteins for fat and protein percentages that were similar to those in Table 8, although fat percentage for Holsteins did not decrease as DD increased beyond $60 \mathrm{~d}$. On a percentage basis, however, Holsteins had a larger increase in both fat (1.7\% for Jerseys vs. $2.2 \%$ for Holsteins) and protein (2.5\% for Jerseys vs. $4.0 \%$ for Holsteins) percentages for $\mathrm{DD} \leq 20$.

SCS. Shortened dry periods had pronounced effects on Jersey SCS, especially dry periods less than $30 \mathrm{~d}$ (Table 8). Cows with dry periods of $20 \mathrm{~d}$ or less averaged 0.31 higher SCS (10\% higher than the overall mean) than cows with 61 to $65 \mathrm{DD}$. Although SCS decreased with 21 to $30 \mathrm{DD}$, cows in this DD category still averaged 0.14 higher SCS than cows with at least $60 \mathrm{DD}$. The substantial, undesirable impact on SCS is largely mitigated by dry periods of at least $45 \mathrm{~d}$. The higher SCS associated with shorter dry periods were somewhat, but by no means completely, related to the lower milk yields associated with shorter dry periods. The mean differences of categories 1,2 , and 3 from category 8 , for exam- ple, were $0.27,0.10$, and 0.06 , respectively, when milk yield was included as a covariate for SCS.

Annen et al. (2004) reported higher SCC for dry periods less than $60 \mathrm{~d}$, which is consistent with the results of this study. In contrast to the results of this study, Gulay et al. (2003) reported a lower SCC with 30 DD than with $60 \mathrm{DD}$ during the first 10 wk of lactation. The comparison was not significantly different from zero and was based on a small sample. Rastani et al. (2005) also found higher SCS for cows with longer dry periods, although differences were not statistically significant. In general, results from the small number of studies that have considered effects of DD on SCS are consistent with the results of this study. The variation observed in results of previous reports almost certainly reflects the small sample sizes in those studies, for a trait subject to large environmental effects.

The biggest difference between the results in Table 8 for Jersey SCS and those presented by Kuhn et al. (2006b) for Holstein SCS was that dry periods less than $20 \mathrm{~d}$ had a considerably larger (undesirable) impact on Jersey SCS than on Holstein SCS. Holsteins, for example, averaged only $0.113(3.7 \%)$ higher SCS for dry periods less than $20 \mathrm{~d}$ and 0.097 (3.1\%) for DD between 21 and $30 \mathrm{~d}$. Another difference was that Holstein SCS continued to decrease with increasing dry period length, even for DD >60, whereas Jersey SCS did not show this tendency and, in fact, were optimal at around $60 \mathrm{DD}$. Jersey producers need to be even more cautious than Holstein producers about dry periods of less than 20 or even $30 \mathrm{~d}$ because the value of the milk in the following lactation will be substantially lowered by higher SCS when DD are $<30 \mathrm{~d}$. 
Table 9. Effects of dry period length on subsequent lactation days open, with and without adjustment for milk yield

\begin{tabular}{lccc}
\hline $\begin{array}{l}\text { Days dry } \\
\text { category }\end{array}$ & $\begin{array}{c}\text { Days } \\
\text { dry }\end{array}$ & $\begin{array}{c}\text { Days open } \\
\text { without milk } \\
\text { adjustment }\end{array}$ & $\begin{array}{c}\text { Days open } \\
\text { with milk } \\
\text { adjustment }\end{array}$ \\
\hline 1 & $0-20$ & $-4 \pm 2.0^{*}$ & $24 \pm 1.7^{* * * *}$ \\
2 & $21-30$ & $-4 \pm 2.0^{*}$ & $18 \pm 1.7^{* * *}$ \\
3 & $31-40$ & $-4 \pm 1.1^{* * *}$ & $10 \pm 1.0^{* * *}$ \\
4 & $41-45$ & $-3 \pm 0.9^{* *}$ & $6 \pm 0.8^{* * *}$ \\
5 & $46-50$ & $-1 \pm 0.7$ & $4 \pm 0.6^{* * *}$ \\
6 & $51-55$ & $-1 \pm 0.6$ & $2 \pm 0.5^{* * *}$ \\
7 & $56-60$ & $-1 \pm 0.6$ & $1 \pm 0.5$ \\
8 & $61-65$ & 0 & 0 \\
9 & $66-70$ & $1 \pm 0.7$ & $1 \pm 0.6^{*}$ \\
10 & $71-80$ & $1 \pm 0.9$ & $4 \pm 0.8^{* * *}$ \\
11 & $81-90$ & $0 \pm 1.3$ & $4 \pm 1.1^{* * *}$ \\
12 & $91-110$ & $-3 \pm 1.2^{*}$ & $3 \pm 1.1^{*}$ \\
13 & $111-130$ & $-6 \pm 1.6^{* * *}$ & $-1 \pm 1.4$ \\
\hline
\end{tabular}

${ }^{1}$ Difference (kg) of: days dry category $i$ minus days dry category 8 $\pm \mathrm{SE}$ of difference, where $i=1$ to $13 ; P$-values correspond to a 2 tailed $t$-test for the null hypothesis of no difference between category $i$ and category 8 .

$* P \leq 0.05 ; * * P \leq 0.01 ; * * * P \leq 0.001$.

DO. Results for DO are given in Table 9. On first inspection, shorter dry periods appear to favor fertility. Cows with 40 or fewer DD averaged 4 fewer DO than cows with 61 to 65 DD. However, this apparent advantage was due entirely to the lower milk yields associated with the shorter dry periods. When DO was adjusted for milk yield, by inclusion of milk yield as a covariate in the model for analysis, short dry periods actually resulted in poorer fertility than dry periods of longer lengths. Cows with only 0 to $20 \mathrm{DD}$ had 24 more DO, when DO was adjusted for yield, than cows with 61 to $65 \mathrm{DD}$; categories $2(18 \mathrm{~d})$ and $3(10 \mathrm{~d})$ still showed considerably higher DO adjusted for milk. With a minimum of about $45 \mathrm{DD}$, however, effects on fertility were small and approached 0 as DD approached $60 \mathrm{~d}$.

There is little published research on the effects of DD on fertility. Compared with the Holstein results presented by Kuhn et al. (2006b), dry period length had smaller effects on Jersey DO (unadjusted for yield) than on Holstein DO, both in absolute terms and on a percentage basis. However, the opposite was true for DO adjusted for milk yield. Although dry periods of $20 \mathrm{~d}$ or less resulted in a 7\% increase in DO adjusted for milk in Holsteins and a 6\% increase in DO for dry periods of 21 to $30 \mathrm{~d}$, Jersey DO increased 18.7 and $14.1 \%$ for these 2 categories. Thus, there does appear to be some difference between the breeds with regard to the interplay among DD, DO, and milk yield; although both have extended DO following lactations with shorter dry periods, when DO is adjusted for yield, the effect is larger in Jerseys than in Holsteins.

Using shortened dry periods to improve fertility in either breed is not likely to be of much overall benefit because the "benefit" in fertility results only from lowered milk yield. It is, first of all, questionable whether improving fertility by lowering milk yield is a prudent economic choice. However, even if improved fertility through lowered milk yield was shown to be of merit, there are almost certainly less expensive or more efficient ways to lower milk yield than by reducing dry period length, a practice that necessarily increases labor, time, and maintenance in the milking parlor, unless herd size is also reduced. Lower cost rations, for example, might lower milk yield and would simultaneously reduce costs rather than increase them, again if improved fertility through lowered milk yield was desired or found to be in some way a favorable alternative.

\section{DD to Maximize Yield Across Lactations}

Adjacent Lactations. Results, along with sample sizes, for Sum12 and Sum23 are given in Table 10. Although production was still lost with shortened dry periods, the losses were, of course, much less than those found for the subsequent lactation because of the mitigating effect of yield gained in the previous lactation. A wide range of dry periods can maximize total yield across adjacent lactations in Jerseys. A minimum of about 45 DD resulted in no loss for either Sum12 or Sum23, but dry periods of up to about $70 \mathrm{~d}$ will also maximize yields across lactations.

Another noticeable result in Table 10 is the difference in DD effects for Sum12 and Sum23, for either short $(<20$ d) or long ( $>80$ d) dry periods. For DD $<20$, milk yield across lactations 1 and 2 was only $76 \mathrm{~kg}$ less than for longer dry periods, whereas $585 \mathrm{~kg}$ of actual milk was lost over lactations 2 and 3 for DD $<20$. Likewise, dry periods of $90 \mathrm{~d}$ or more resulted in nearly twice the amount of loss for Sum23 compared with Sum12. The greater persistency of first-lactation cows (Stanton et al., 1992) provides an explanation for both of these differences. For DD $<20$, the higher production of firstlactation cows in the later stages of lactation results in more compensation in the previous lactation yield for Sum12 than for Sum23. To understand the smaller effect of long DD on Sum12 than Sum23, it should be noted (as was shown in Table 6) that long dry periods are also associated with long DO and that long DO, in turn, are associated with longer lactations. Thus, the higher production of first-lactation cows in late (long) lactations also helps to offset losses associated with long dry periods because cows with long DD also stayed in milk longer, in the lactation preceding the dry period, than cows with shorter dry periods.

Jersey DD effects for Sum12 and Sum23 generally showed patterns similar to that reported for Holsteins 
Table 10. Effects of dry period length on total milk yield across lactations 1 and 2 (Sum12), and 2 and 3 (Sum23)

\begin{tabular}{|c|c|c|c|c|c|}
\hline \multirow[b]{2}{*}{$\begin{array}{l}\text { Days dry } \\
\text { category }\end{array}$} & \multirow[b]{2}{*}{ Days dry } & \multicolumn{2}{|c|}{ Sum12 } & \multicolumn{2}{|c|}{ Sum23 } \\
\hline & & $\begin{array}{l}\text { No. of } \\
\text { records }\end{array}$ & Differences $^{1}$ & $\begin{array}{l}\text { No. of } \\
\text { records }\end{array}$ & Differences $^{1}$ \\
\hline 1 & $0-20$ & 859 & $-76 \pm 54.0$ & 311 & $-585 \pm 100.4^{* * *}$ \\
\hline 2 & $21-30$ & 773 & $-231 \pm 55.3^{* * *}$ & 313 & $-215 \pm 99.5^{*}$ \\
\hline 3 & $31-40$ & 2,858 & $-87 \pm 30.7^{* *}$ & 1,227 & $-171 \pm 53.8^{* * *}$ \\
\hline 4 & $41-45$ & 4,338 & $-86 \pm 25.4^{* * *}$ & 1,805 & $-178 \pm 44.4^{* * *}$ \\
\hline 5 & $46-50$ & 8,388 & $-14 \pm 19.5$ & 3,662 & $-43 \pm 33.7$ \\
\hline 6 & $51-55$ & 13,815 & $-21 \pm 16.2$ & 6,007 & $-32 \pm 28.0$ \\
\hline 7 & $56-60$ & 16,668 & 0 & 7,526 & 0 \\
\hline 8 & $61-65$ & 12,273 & $-21 \pm 16.6$ & 6,353 & $27 \pm 27.2$ \\
\hline 9 & $66-70$ & 5,741 & $-4 \pm 21.7$ & 3,143 & $-31 \pm 34.5$ \\
\hline 10 & $71-80$ & 3,353 & $-154 \pm 27.3^{* * * *}$ & 1,969 & $-306 \pm 41.4^{* * *}$ \\
\hline 11 & $81-90$ & 1,373 & $-192 \pm 39.9 * * *$ & 940 & $-430 \pm 56.1^{* * *}$ \\
\hline 12 & $91-110$ & 1,532 & $-322 \pm 38.1^{* * * *}$ & 1,144 & $-691 \pm 51.6^{* * *}$ \\
\hline 13 & $111-130$ & 908 & $-476 \pm 48.6^{* * * *}$ & 691 & $-813 \pm 64.7 * * *$ \\
\hline
\end{tabular}

${ }^{1}$ Difference in sums: days dry category $i$ minus days dry category $7 \pm \mathrm{SE}$ of difference, where $i=1$ to 13 ; $P$-values correspond to a 2 -tailed $t$-test for the null hypothesis of no difference between category $i$ and category 7.

$* P \leq 0.05 ; * * P \leq 0.01 ; * * * P \leq 0.001$.

by Kuhn et al. (2006a). The major difference was that long dry periods were less costly for Holsteins than for Jerseys. For DD of 70 d or more, Sum 12 did not show a loss in Holsteins, and the percentage loss for Jerseys was higher for Sum23 than for Holsteins. Schutz et al. (1990) reported greater persistency for Holsteins than for Jerseys in both first and second lactations, which would explain the smaller losses of Holsteins with long dry periods.

Dry Period in First Lactation to Maximize Total Yield Across Lactations 1, 2, and 3. Results, as well as sample sizes, for Sum123 are given in Table 11. Losses in total yield across the first 3 lactations were substantially higher for both short $(<45 \mathrm{~d})$ and long ( $>70$ d) dry periods than for Sum12. The larger effect of DD1 on Sum123 than on Sum12 can be explained, at least in part, by DIM, culling, or both in the second and third lactations. The average total DIM across lactations 2 and 3, in Table 11, illustrate that cows with either short or long dry periods after the first lactation have fewer DIM in subsequent lactations. The percentage of cows culled after the second lactation, by DD category, is also shown in Table 11. The percentages culled show, in turn, that the fewer DIM for either short or long dry periods are due, at least in part, to greater culling. Thus, dry period length after the first lactation affects total yield across the first 3 lactations, in part by affecting DIM and culling. A minimum of about 45 DD after the first lactation is necessary to maximize total yield across lactations 1,2 , and 3 . Dry periods longer than $65 \mathrm{~d}$ after the first lactation also result in lost lifetime yield, not only because cows with DD1
$>65$ have fewer total DIM, but also because of greater culling among these cows.

Recent interest in dry period length has focused on the viability of dry periods shorter than $60 \mathrm{~d}$. However, results for Sum 123 emphasize the considerable cost, in lost production, associated with long dry periods ( $>70$ d). Cows with 80 to $90 \mathrm{DD}$, for example, produce about $2,000 \mathrm{~kg}$ less milk across lactations 1, 2, and 3, compared with cows with 45 to $65 \mathrm{DD}$, whereas cows with 110 to 130 DD produce almost 3,000 kg less milk. Results in Table 6 showed that part of the reason for long dry periods is long DO. Thus, these results reiterate and emphasize the importance of good fertility. Good fertility will not only be necessary for implementation of shorter dry periods, if such a practice is desired, but is also needed to avoid costly dry periods of long length.

\section{CONCLUSIONS}

Of the factors considered in this research, the primary ones affecting dry period length in Jerseys were DO, milk yield, and SCS on the last test-day. Cows with longer DO, lower milk yield, and higher SCS received longer dry periods.

The biggest difference between Jerseys and Holsteins, with regard to DD effects in the subsequent lactation, was a much larger detrimental effect on SCS in Jerseys for dry periods of $30 \mathrm{~d}$ or less. Jersey SCS was $10 \%$ higher, relative to the overall mean, for dry periods of $20 \mathrm{~d}$ or less. Jersey producers, especially, should be skeptical of dry periods less than $30 \mathrm{~d}$, because the value of the milk will be reduced in the following lactation due to substantially higher SCS. 
Table 11. Effects of first-lactation dry period length on total yield across lactations 1, 2, and 3 (Sum123), total DIM for lactations 2 and 3, and percent culled after second lactation

\begin{tabular}{|c|c|c|c|c|c|}
\hline $\begin{array}{l}\text { Days dry } \\
\text { category }\end{array}$ & $\begin{array}{l}\text { Days dry } \\
\text { after 1st } \\
\text { lactation }\end{array}$ & $\begin{array}{l}\text { No. of } \\
\text { records }\end{array}$ & Differences $^{2}$ & $\begin{array}{c}\text { Average } \\
\text { DIM }^{3}\end{array}$ & Culled, ${ }^{4} \%$ \\
\hline 1 & $0-20$ & 686 & $-779 \pm 215^{* * * *}$ & 491 & 53.4 \\
\hline 2 & $21-30$ & 620 & $-974 \pm 218^{* * * *}$ & 499 & 51.5 \\
\hline 3 & $31-40$ & 2,163 & $-583 \pm 123 * * *$ & 510 & 47.2 \\
\hline 4 & $41-45$ & 3,418 & $-224 \pm 100 *$ & 521 & 41.5 \\
\hline 5 & $46-50$ & 6,919 & $-77 \pm 76$ & 521 & 41.2 \\
\hline 6 & $51-55$ & 11,647 & $6 \pm 62$ & 518 & 41.3 \\
\hline 7 & $56-60$ & 14,310 & 0 & 514 & 41.7 \\
\hline 8 & $61-65$ & 10,641 & $-103 \pm 63$ & 509 & 43.1 \\
\hline 9 & $66-70$ & 4,938 & $-324 \pm 83 * * *$ & 497 & 45.4 \\
\hline 10 & $71-80$ & 2,938 & $-990 \pm 104^{* * * *}$ & 490 & 46.4 \\
\hline 11 & $81-90$ & 1,222 & $-2,004 \pm 150$ *** & 459 & 53.7 \\
\hline 12 & $91-110$ & 1,355 & $-2,302 \pm 144^{* * *}$ & 451 & 54.0 \\
\hline 13 & $111-130$ & 811 & $-2,986 \pm 182^{* * *}$ & 436 & 55.0 \\
\hline
\end{tabular}

Effects on Jersey production in the subsequent lactation were similar to previous reports for Holsteins, at least on a percentage basis. Jersey milk, fat, and protein yields in the subsequent lactation were maximized with 61 to 65 DD. Dry periods of $30 \mathrm{~d}$ or less resulted in especially large reductions in subsequent lactation production. With a minimum of approximately $45 \mathrm{DD}$, production losses in the following lactation were reduced to about $255 \mathrm{~kg}$ of milk, $9 \mathrm{~kg}$ of fat, and $7 \mathrm{~kg}$ of protein.

As previously reported for Holsteins, fat and protein percentages for Jerseys were actually favored by shortened dry periods, and this was not due to the lowered milk yield associated with shortened DD. The net effect of DD on DO was fewer DO with shorter dry periods and was less for Jerseys than the effects previously published for Holsteins. This reduction in DO, however, was due entirely to the lower milk yields associated with shortened dry periods. When adjusted for milk yield, the advantage in DO was completely nullified and, in fact, short dry periods actually resulted in poorer fertility when DO was adjusted for yield. Given that the only benefit to fertility of shortened DD is due to lower milk yield, it is unlikely that "improved" fertility is a viable reason for shortening dry periods.

Although further research would be needed in Jerseys to determine the long-term consequences of DD after second and later lactations, it is recommended that Jersey producers maintain dry periods of between 45 and $60 \mathrm{~d}$, at least after the first lactation; $60 \mathrm{DD}$ are at least as acceptable, in terms of performance, as are shorter dry periods. There is no benefit to production in either the short or long term of dry periods less than $45 \mathrm{~d}$; furthermore, the value of milk produced following lactations with dry periods of $<30$ or even $<45 \mathrm{~d}$ will be lower than for dry periods of at least $45 \mathrm{~d}$ because of the higher SCS.

Given the recent advocacy for shortened dry periods, it is worthwhile to emphasize that 61 to $65 \mathrm{DD}$ does provide optimal production and performance, although as few as $45 \mathrm{DD}$ can as well; there are no production advantages for dry periods less than $60 \mathrm{~d}$. This research has also underscored the need for good fertility. Cows with long DO have longer dry periods, on average, which in turn results in substantial lost production across the lifetime of a cow. Considering, then, the need to avoid both short and long dry periods, and given some variation in gestation length, a target dry period length of $55 \mathrm{~d}$ will serve Jersey producers well; if cows calve even $10 \mathrm{~d}$ earlier (45 DD) or $10 \mathrm{~d}$ later (65 DD) than expected, little, if anything, will be lost.

\section{ACKNOWLEDGMENTS}

The authors thank Shogo Tsuruta and Ignacy Misztal for the use of their AIREMLF90 program and Tianlin Wang, Rohan Fernando, and Steve Kachman for the use of their Matvec software. The cooperation of the dairy records processing centers in supplying yield and pedigree data for use in genetic and management research is acknowledged, as are the American dairy farmers who pay for data collection in the United States. The authors also thank Cari Wolfe of the Ameri- 
can Jersey Cattle Association for comments and for prompting this research, as well as Mike Hutjens for constructive suggestions prior to submission. Finally, the 2 anonymous journal reviewers are gratefully acknowledged for providing a very prompt review.

\section{REFERENCES}

AIPL (Animal Improvement Programs Laboratory). 2006. Trend in milk breeding values for Holstein calculated August, 2006. http:// aipl.arsusda.gov/dynamic/trend/current/trndx.html Accessed Sept. 18, 2006.

Annen, E. L., R. J. Collier, M. A. McGuire, J. L. Vicini, J. M. Ballam, and M. J. Lormore. 2004. Effect of modified dry period lengths and bovine somatotropin on yield and composition of milk from dairy cows. J. Dairy Sci. 87:3746-3761.

Bachman, K. C. 2002. Milk production of dairy cows treated with estrogen at the onset of a short dry period. J. Dairy Sci. 85:797-803.

Capuco, A. V., R. M. Akers, and J. J. Smith. 1997. Mammary growth in Holstein cows during the dry period: Quantification of nucleic acids and histology. J. Dairy Sci. 80:477-487.

Coppock, C. E., R. W. Everett, R. P. Natzke, and H. R. Ainslie. 1974. Effect of dry period length on Holstein milk production and selected disorders at parturition. J. Dairy Sci. 57:712-718.

Dias, F. M., and F. R. Allaire. 1982. Dry period to maximize milk production over two consecutive lactations. J. Dairy Sci. 65:136-145.

Funk, D. A., A. E. Freeman, and P. J. Berger. 1987. Effects of pervious days open, previous days dry, and present days open on lactation yield. J. Dairy Sci. 70:2366-2373.

Gulay, M. S., M. J. Hayen, K. C. Bachman, T. Belloso, M. Liboni, and H. H. Head. 2003. Milk production and feed intake of Holstein cows given short (30-d) or normal (60-d) dry periods. J. Dairy Sci. 86:2030-2038.

Gulay, M. S., M. J. Hayen, H. H. Head, C. J. Wilcox, and K. C. Bachman. 2005. Milk production from Holstein half udders after concurrent thirty- and seventy-day dry periods. J. Dairy Sci. 88:3953-3962

Kuhn, M. T., and J. L. Hutchison. 2005. Methodology for estimation of days dry effects. J. Dairy Sci. 88:1499-1508.

Kuhn, M. T., J. L. Hutchison, and H. D. Norman. 2005a. Characterization of days dry in United States Holsteins. J. Dairy Sci. 88:1147-1155.
Kuhn, M. T., J. L. Hutchison, and H. D. Norman. 2005b. Minimum days dry to maximize milk yield in subsequent lactation. Anim. Res. 54:351-367.

Kuhn, M. T., J. L. Hutchison, and H. D. Norman. 2006a. Dry period length to maximize production across adjacent lactations and lifetime production. J. Dairy Sci. 89:1713-1722.

Kuhn, M. T., J. L. Hutchison, and H. D. Norman. 2006b. Effects of length of dry period on yields of milk fat and protein, fertility and milk somatic cell score in the subsequent lactation of dairy cows. J. Dairy Res. 73:154-162.

Madsen, T. G., J. B. Andersen, K. L. Ingvartsen, and M. O. Nielsen. 2004. Continuous lactation in dairy cows: Effects on feed intake, milk production and mammary nutrient extraction. J. Anim. Feed Sci. 13:503-506.

Makuza, S. M., and B. T. McDaniel. 1996. Effects of days dry, previous days open, and current days open on milk yields of cows in Zimbabwe and North Carolina. J. Dairy Sci. 79:702-709.

NRC. 1989. Nutrient Requirements of Dairy Cattle. 6th rev. ed. Natl. Acad. Sci., Washington, DC.

Rastani, R. R., R. R. Grummer, S. J. Bertics, A. Gümen, M. C. Wiltbank, D. G. Mashek, and M. C. Schwab. 2005. Reducing dry period length to simplify feeding transition cows: Milk production, energy balance, and metabolic profiles. J. Dairy Sci. 88:10041014.

Rémond, B., A. Ollier, and G. Miranda. 1992. Milking of cows in late pregnancy: Milk production during this period and during the succeeding lactation. J. Dairy Res. 59:233-241.

Sargent, F. D., V. H. Lytton, and O. G. Wall, Jr. 1968. Test interval method of calculating dairy herd improvement association records. J. Dairy Sci. 51:170-179.

SAS Institute. 2004. OnlineDoc. Version 9.1.2. SAS Inst., Inc., Cary, NC.

Schaeffer, L. R., and C. R. Henderson. 1972. Effects of days dry and days open on Holstein milk production. J. Dairy Sci. 55:107-112.

Schutz, M. M., L. B. Hansen, G. R. Steuemagel, and A. L. Kuck. 1990. Variation of milk, fat, protein, and somatic cells for dairy cattle. J. Dairy Sci. 73:484-493.

Shook, G. E., L. P. Johnson, and F. N. Dickinson. 1980. Factors for improving accuracy of estimates of test-interval yield. DHI Lett. 56:9-24.

Sørensen, J. T., and C. Enevoldsen. 1991. Effect of dry period length on milk production in subsequent lactation. J. Dairy Sci. 74:1277-1283.

Stanton, T. L., L. R. Jones, R. W. Everett, and S. D. Kachman. 1992. Estimating milk, fat, and protein lactation curves with a test day model. J. Dairy Sci. 75:1691-1700. 